\title{
Uptake and distribution of a copper, iron and zinc mixture in gill, liver and plasma of a freshwater teleost, Tilapia sparrmanii
}

\author{
V Wepener ${ }^{1 *}$, JHJ van Vuren ${ }^{2}$ and $\mathrm{HH}$ du Preez ${ }^{2}$ \\ ${ }^{1}$ Coastal Research Unit of Zululand, Department of Zoology, University of Zululand, Private Bag X1001, Kwadlangezwa 3886, \\ KwaZulu-Natal, South Africa \\ ${ }^{2}$ Department of Zoology, Rand Afrikaans University, PO Box 524, Auckland Park 2006, Johannesburg, South Africa
}

\begin{abstract}
Since polluted environments contain mixtures of different contaminants, the aim of this study was to investigate the time-integrated uptake of individual metals by a freshwater teleost, Tilapia sparrmanii following exposure to a metal mixture containing $\mathrm{Cu}, \mathrm{Fe}$ and $\mathrm{Zn}$. The metal concentrations used during the bioassays were chosen to represent ecologically relevant concentrations as found in the Olifants River, Kruger National Park, South Africa. The concentrations used in the bioassay were $0.16 \mathrm{mg} \cdot \mathrm{I}^{-1}, 4.3 \mathrm{mg} \cdot \mathrm{I}^{-1}$ and $\left.1.003 \mathrm{mg} \cdot\right|^{-1}$ for $\mathrm{Cu}, \mathrm{Fe}$ and $\mathrm{Zn}$ respectively. Gill, plasma and liver were sampled at $0,2,4,6,12,24,24,48,72,96 \mathrm{~h}$ and four weeks. Gill tissue is the initial site of accumulation of water-borne metals. Although the fish were exposed to a metal mixture, the interactions between metals and the external gill surface, as well as the subsequent uptake rate, were associated with the particular chemical properties of individual metals. The tendency of the individual metals in the metal mixture to bind to the external gill surface via ionic bonds, and to gill cytosolic compounds via covalent bonds, was $\mathrm{Cu}>\mathrm{Fe}>\mathrm{Zn}$. The ensuing uptake rates into the extracellular compartment (blood) and intracellular compartment (liver tissue) were $\mathrm{Zn}>\mathrm{Fe}>\mathrm{Cu}$. The toxic effects of $\mathrm{Cu}$ and $\mathrm{Fe}$ were, therefore, primarily exerted on the gill surface and in the gill cytosol, whereas the toxic action of $\mathrm{Zn}$ was primarily limited to the internal organs.
\end{abstract}

\section{Introduction}

Trace metals are introduced into the environment by a wide spectrum of natural and anthropogenic sources. Metals are nonbiodegradable, and once they enter the environment, bioconcentration may occur in fish tissue by means of metabolic and biosorption processes (Hodson, 1988; Carpené et al., 1990; Wicklund-Glynn, 1991). From an environmental point of view, bioconcentration is important because metal ions usually occur in low concentrations in the aquatic environment and subtle physiological effects go unnoticed until gross chronic reactions (e.g. changes in populations structure, altered reproduction, etc.) become apparent (Kumar and Mathur, 1991). Although trace metals are essential for normal physiological processes, abnormally high concentrations can be toxic to aquatic organisms. Due to the insidious nature of metal bioconcentration, it would be too late to apply preventative measures to reduce the pollution effects by the time the chronic effects become visible.

Acute metal toxicity in fish is often characterised by gill damage and hypersecretion of mucus (Mallatt, 1985). Ensuing mortalities are, in turn, related to secondary physiological respiratory disturbances, resulting in ion-regulatory and acid-base balance disturbances (Goss and Wood, 1988). The extent of the physiological disturbances will depend on bioconcentration and uptake of the metal, which, in turn, is determined by the physical and chemical composition of the surrounding medium.

Most research has been concerned with the physiological effects and bioconcentration patterns of individual metals. Trace metals i.e. $\mathrm{Cu}, \mathrm{Fe}$ and $\mathrm{Zn}$ are readily concentrated in different fish tissues (Villegas-Navarro and Villarreal-Treviño, 1989; Grobler-

\footnotetext{
* To whom all correspondence should be addressed.

푱(035) 902-6741; fax(035) 902-6750; e-mail: vwepener@pan.uzulu.ac.za Received 10 December 1999; accepted in revised form 15 September 2000
}

Van Heerden et al., 1991; Mohan and Choudhary, 1991; Peres and Pihan, 1991; Pelgrom et al., 1995). It has further been shown that uptake of sublethal concentrations of these metals leads to altered physiological processes, which reduces the normal functioning of the organism (Grobler et al., 1989; Wepener et al., 1992). As effluent from many sources enters natural waters, the negative impact on the aquatic ecosystem is due to a mixture of metals, rather than individual component metals. When metal mixtures are discharged into the environment they may show a number of effects, which are synergistic, antagonistic or additive in nature (Lewis, 1978; Tsai and McKee, 1980; Mukhopadhyay and Konar, 1985).

Research on the interaction of $\mathrm{Cu}, \mathrm{Zn}$ and $\mathrm{Fe}$ and the subsequent tissue distribution is limited mainly to mammalian toxicological studies, investigating the absorption and metabolism of these metals under high and low dietary conditions (see Gawthorne, 1987 for extensive review). Very limited work, other than a study by Dethloff et al. (1999) investigating the uptake of $\mathrm{Cu}$ and $\mathrm{Zn}$ by gill and liver tissue of rainbow trout exposed to a metal mixture containing $\mathrm{Cu}$ and $\mathrm{Zn}$, has been done on uptake of individual metals by fish following their exposure to a metal mixture.

Metal exposure concentrations were selected to represent ecologically relevant concentrations. The Olifants River (Mpumalanga) is known to contain high $\mathrm{Cu}$ and $\mathrm{Zn}$ concentrations, which are comparable to metal concentrations in large metalpolluted rivers in the northern hemisphere (Wepener et al., 2000). Concentrations selected for this study were based on actual measured values obtained during a metal monitoring programme in the Olifants River (Seymore et al., 1994). The purpose of this paper was to evaluate the bioconcentration kinetics and tissue distribution of individual metals from a metal mixture containing $\mathrm{Cu}, \mathrm{Fe}$ and $\mathrm{Zn}$ in gill, liver and plasma in a freshwater fish, Tilapia sparrmanii. This information could contribute to understanding physiological responses following exposure to metal mixtures containing $\mathrm{Cu}, \mathrm{Fe}$ and $\mathrm{Zn}$. 

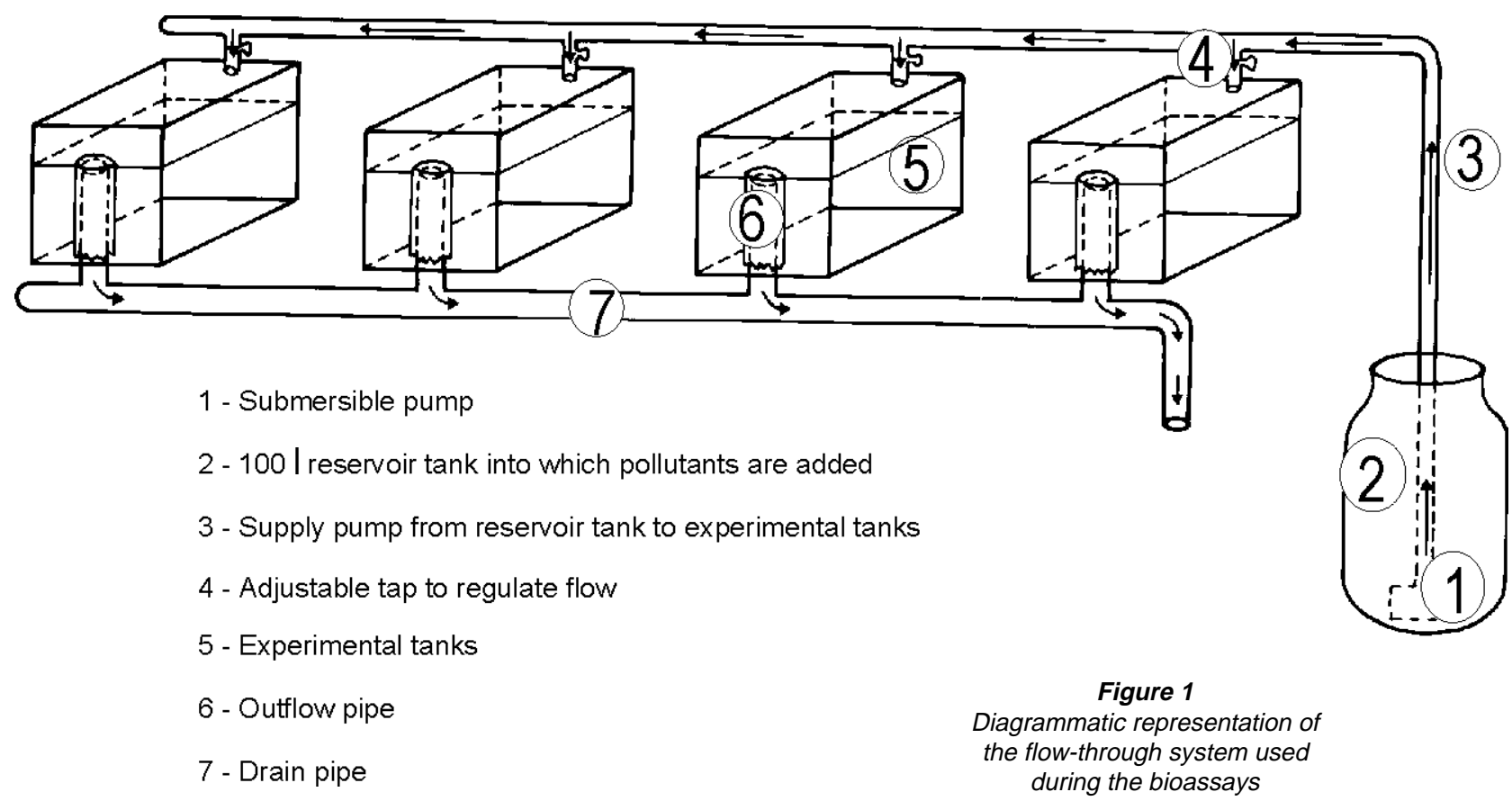
Diagrammatic representation of the flow-through system used during the bioassays

Figure 1

\begin{tabular}{|c|c|}
\hline \multicolumn{2}{|c|}{$\begin{array}{l}\text { TABLE } 1 \\
\text { Water quality of the exposure medium used } \\
\text { during bioassays. Only pH was measured daily } \\
\text { during each exposure and the mean standard } \\
\text { deviation is presented. All the other variables } \\
\text { were measured at the onset of the bioassays. }\end{array}$} \\
\hline $\mathrm{pH}$ & $7.6 \pm 0.1$ \\
\hline Ammonium $\left(\mathrm{mg} \cdot \mathrm{l}^{-1}\right)$ & 0.04 \\
\hline Fluoride $\left(\mathrm{mg} \cdot \cdot^{-1}\right)$ & 0.1 \\
\hline Total Alkalinity as $\mathrm{CaCO}_{3}\left(\mathrm{mg} \cdot \mathrm{l}^{-1}\right)$ & 50 \\
\hline Potassium $\left(\left.\mathrm{mg} \cdot\right|^{-1}\right)$ & 1 \\
\hline Sodium $\left(\left.\mathrm{mg} \cdot\right|^{-1}\right)$ & 5 \\
\hline Chloride $\left(\mathrm{mg} \cdot \mathrm{l}^{-1}\right)$ & 10 \\
\hline Calcium $\left(\mathrm{mg} \cdot \mathrm{l}^{-1}\right)$ & 11 \\
\hline $\operatorname{Magnesium}\left(\left.\mathrm{mg} \cdot\right|^{-1}\right)$ & 9 \\
\hline Ortho-phosphate $\left(\mathrm{mg} \cdot \mathrm{l}^{-1}\right)$ & 0.015 \\
\hline Sulphate $\left(\left.\mathrm{mg} \cdot\right|^{-1}\right)$ & 10 \\
\hline Electrical conductivity $(\mathrm{mS} / \mathrm{m})$ at $25^{\circ} \mathrm{C}$ & 17.7 \\
\hline Copper $\left(\left.\mu \mathrm{g} \cdot\right|^{-1}\right)$ & 24 \\
\hline $\operatorname{Iron}\left(\left.\mu \mathrm{g} \cdot\right|^{-1}\right)$ & 319 \\
\hline $\operatorname{Zinc}\left(\left.\mu \mathrm{g} \cdot\right|^{-1}\right)$ & 149 \\
\hline
\end{tabular}

\section{Material and methods}

\section{Bioindicators and bioassay system}

Banded tilapia (T. sparrmanii), averaging $170 \pm 13 \mathrm{~mm}$ in length and $74 \pm 8 \mathrm{~g}$ in mass were obtained from a commercial hatchery in Brits, Northwest Province, South Africa. Prior to experimental use the fish were kept in a tank containing 2500 I aerated, circulated and filtered water at $28 \pm 0.5^{\circ} \mathrm{C}$. The fish were fed daily with commercial trout pellets ( $40 \%$ protein).

Following acclimation to laboratory conditions for a period of four months, healthy fish were transferred to $12 \times 100 \mathrm{I}$ aerated glass aquarium tanks (ten fish per tank) of the experimental flow- through system (Fig. 1) and they were allowed to acclimatise in the experimental tanks for at least one week prior to metal exposure. Borehole water was used during the entire acclimation and experimental period and the chemical water quality attributes during the study are presented in Table 1 .

The water temperature of the experimental tanks was kept at $28 \pm 0.5^{\circ} \mathrm{C}$ and a pH of $7.6 \pm 0.1$ was maintained. The fish were subjected to a $14 \mathrm{~h}$ light and $10 \mathrm{~h}$ dark rhythms. These conditions simulated the conditions which prevailed in the Olifants River during the summer months (Seymore et al., 1994). The concentrations of $\mathrm{Cu}, \mathrm{Fe}$ and $\mathrm{Zn}$ chosen for this experiment represented the mean total concentrations of these metals in the Olifants River during 1990 to 1991 (Seymore et al., 1994). The concentrations used during this bioassay were $0.16 \mathrm{mg} \cdot \mathrm{l}^{-1}$, $4.3 \mathrm{mg} \cdot \mathrm{l}^{-1}$ and $1.003 \mathrm{mg} \cdot \mathrm{l}^{-1}$ for $\mathrm{Cu}, \mathrm{Fe}$ and $\mathrm{Zn}$ respectively. Metals were added to 1000 I reservoir tanks as $\mathrm{CuCl}_{2}, \mathrm{FeCl}_{2}$ and $\mathrm{ZnCl}_{2}$ solutions. Each reservoir supplied a set of four 100 I glass tanks with the toxicant mixture through an adjustable tap (Fig. 1). Each tank contained 10 fish and the flow rate was maintained at 90 $\mathrm{ml} \cdot \mathrm{min}^{-1}$. Control fish were maintained under similar conditions, but without the addition of the metal mixture to the water.

Short-term exposure of $T$. sparrmanii to the metal mixture (2 to $96 \mathrm{~h}$ ) and also long-term exposure of four weeks were effected. Short-term exposure regimes consisted of test animals being exposed to the metal mixture for $2,4,6,12,24,48,72$ and $96 \mathrm{~h}$ simultaneously. Five test organisms were used for the $2 \mathrm{~h}$ to $72 \mathrm{~h}$ exposure periods, whereas 10 test organisms were used for the control, $96 \mathrm{~h}$ and longterm exposure periods $(672 \mathrm{~h})$. A reduction in the sample size for the intermediate time-interval exposures was necessitated due to the size constraints of the bioassay system and the availability of test organisms. None of the fish were fed during the $96 \mathrm{~h}$ exposure period, whereas during the long-term exposure, fish were fed every second day. Care was taken to ensure that no excess food was left in the tanks after feeding.

Water samples were taken after $96 \mathrm{~h}$ and long-term exposure $(672 \mathrm{~h})$ and metal concentrations were measured. After acidification of the water samples, total concentrations (unfiltered water) of $\mathrm{Cu}$, Fe and $\mathrm{Zn}$ were measured by atomic absorption spectrophotometry. 
The concentrations of the metals in the exposure mixture after 96 $\mathrm{h}$ were as follows: $\mathrm{Cu}-0.154 \pm 0.01 \mathrm{mg} \cdot \mathrm{l}^{-1}, \mathrm{Fe}-3.8 \pm 0.3 \mathrm{mg} \cdot \mathrm{l}^{-1}$ and $\mathrm{Zn}-0.966 \pm 0.04 \mathrm{mg} \cdot \mathrm{l}^{-1}$ and after 4 weeks metal concentrations were: $\mathrm{Cu}-0.168 \pm 0.014 \mathrm{mg} \cdot \mathrm{l}^{-1}, \mathrm{Fe}-2.95 \pm 0.28 \mathrm{mg} \cdot \mathrm{l}^{-1}$ and $\mathrm{Zn}-$ $0.982 \pm 0.028 \mathrm{mg} \cdot \mathrm{l}^{-1}$.

\section{Tissue concentrations}

Following exposure to the metal mixture for 2, 4, 6, 12, 24, 48, 72 and $96 \mathrm{~h}$ as well as $672 \mathrm{~h}$, fish were removed from the experimental tanks. Blood was collected from the dorsal aorta. Thereafter, the fish were killed by severing the spinal cord and dissecting the gill and liver tissue. Mucus was removed from the gill surface by gently swirling the gill tissue in distilled water. Tissue samples for the control, $96 \mathrm{~h}$ exposure and long-term exposure were collected from ten fish, whereas tissues were only collected from five fish in the other exposure groups. This was due to practical reasons associated with the availability of test organisms. In order to obtain sufficient sample volume ( $1 \mathrm{ml}$ of plasma) for metal analyses, it was necessary to pool the plasma samples from individual fish during each exposure group. It was, therefore, not possible to analyse replicate plasma samples for each exposure group. The same procedure had to be applied to some of the short-term exposures in order to obtain sufficient liver mass for analyses. Although it was not the ideal situation, it was assumed that, in both cases, analyses of pooled samples from 5 organisms would be sufficient to reduce variability. Tissues were placed in pre-weighed flasks and allowed to dry in a drying oven for $24 \mathrm{~h}$ at $60^{\circ} \mathrm{C}$. Further sample preparation, sample analyses and calculations were carried out as described in detail by Du Preez and Steyn (1992). Statistical analyses were carried out using the unpaired Student's t-test (Zar, 1996).

\section{Results}

\section{Metal concentrations in gill tissue}

Copper concentrations in gill tissue showed slight increases for the first $48 \mathrm{~h}$. Thereafter, the levels increased significantly $(\mathrm{P}<0.05)$ and remained significantly elevated after four weeks of exposure (Fig. 2a). Iron in gill tissue increased significantly $(\mathrm{P}<0.05)$ after only $2 \mathrm{~h}$ exposure and remained elevated during the $72 \mathrm{~h}$ exposure period (Fig. 2b). The Fe concentrations after the $96 \mathrm{~h}$ exposure period did not differ from the control values, but long-term exposure to the metal mixture resulted in significantly elevated concentrations. In contrast to the increases in $\mathrm{Cu}$ and $\mathrm{Fe}$, following exposure to the metal mixture, $\mathrm{Zn}$ concentrations in the gill tissue decreased significantly during the initial $12 \mathrm{~h}$ of exposure (Fig. 2c). The following $48 \mathrm{~h}$ exposure period resulted in increases in $\mathrm{Zn}$ concentrations, but the levels were still significantly lower than those of the control values. Concentrations of $\mathrm{Zn}$ in gill tissue returned to control levels after $96 \mathrm{~h}$ of exposure and remained within these levels, even after four weeks of exposure.

\section{Metal concentrations in plasma}

Concentrations of $\mathrm{Cu}$ in plasma samples of $T$. sparrmanii showed a marked decrease from the control concentrations following shortterm exposure to the metal mixture (Fig. 3). Elevated concentrations were only found after long-term exposure. Bioconcentration patterns for $\mathrm{Zn}$ revealed intermittent increases and decreases in the plasma samples (Fig. 3c). Concentrations initially increased during the first $4 \mathrm{~h}$ of exposure, followed by a decrease to control values during the $12 \mathrm{~h}$ exposure period. This was followed by "pulsed"
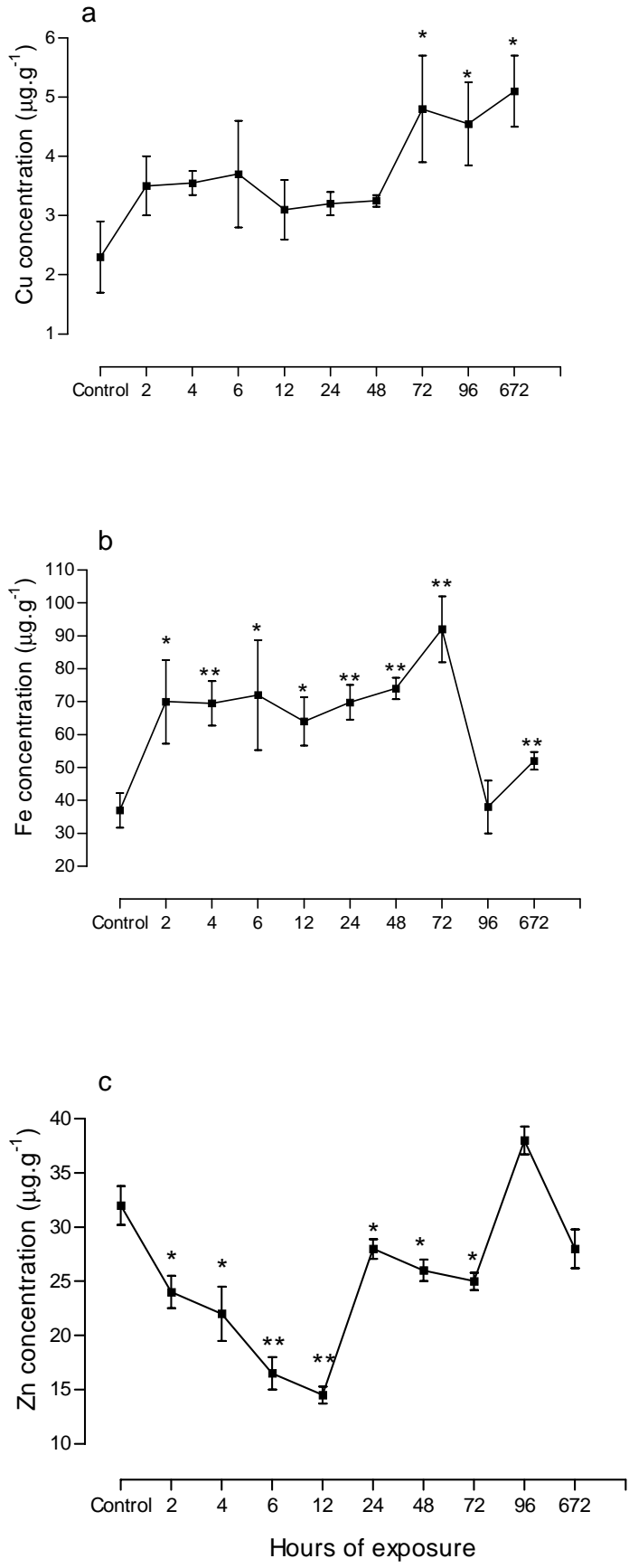

Figure 2

Time-dependent bioconcentration of copper, iron and zinc in gill tissue of $\mathrm{T}$. sparrmanii. Concentrations are presented as mean \pm standard error. Asterisks represent significant differences $\left({ }^{*}-P<0.05\right.$ and $\left.{ }^{* *}-P<0.005\right)$ from the control values $(n=5$ for all exposures except $0 h, 96 h$ and $672 h$ where $n=10)$. Note the $x$-axis is not according to scale.

uptake after $24 \mathrm{~h}$ exposure and decreased to normal and below normal values after 36 and $48 \mathrm{~h}$ exposures respectively. The $72 \mathrm{~h}$ exposure group displayed increased $\mathrm{Zn}$ concentrations, whereas the $96 \mathrm{~h}$ exposure reflected lower concentrations when compared to control values. Long-term exposure to the metal mixture resulted in elevated $\mathrm{Zn}$ concentrations. Bioconcentration of $\mathrm{Fe}$ in plasma displayed similar patterns to that of $\mathrm{Zn}$, but the frequency of the increase/decrease "pulses" was much lower. Plasma Fe concen- 

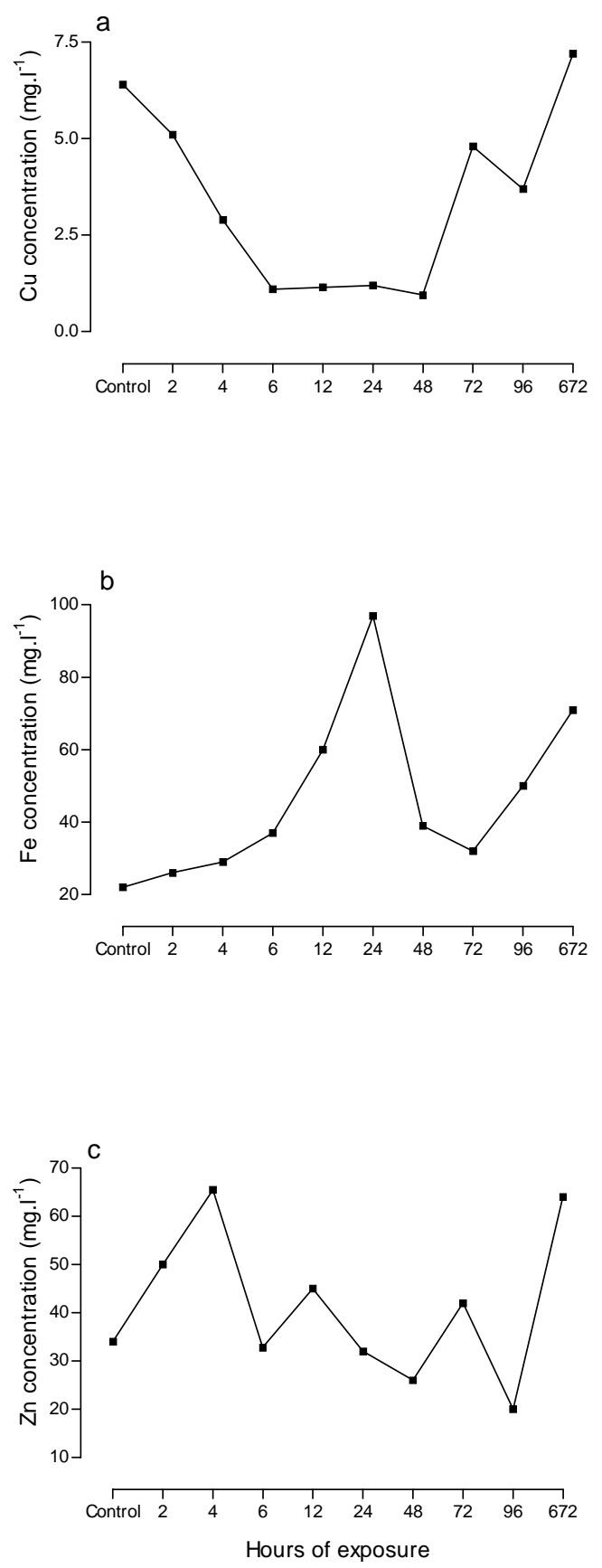

Figure 3

Time dependent bioconcentration of copper, iron and zinc in plasma of T. sparrmanii. Plasma samples were pooled to obtain 1 $\mathrm{ml}$ of plasma for each exposure group ( $n=5$ for all exposures except $0 h, 96 h$ and $672 h$ where $n=10$ ). Hence, the lack of replicates. Note the $x$-axis is not according to scale.

trations increased steadily and reached a maximum after $24 \mathrm{~h}$ of exposure and then decreased to near control values during the subsequent $48 \mathrm{~h}$ exposure (Fig. 3b). Increases in Fe concentrations above controls were measured following the $96 \mathrm{~h}$ exposure and long-term exposure periods.

\section{Metal concentrations in liver tissue}

Copper, $\mathrm{Fe}$ and $\mathrm{Zn}$ concentrations in liver tissue decreased
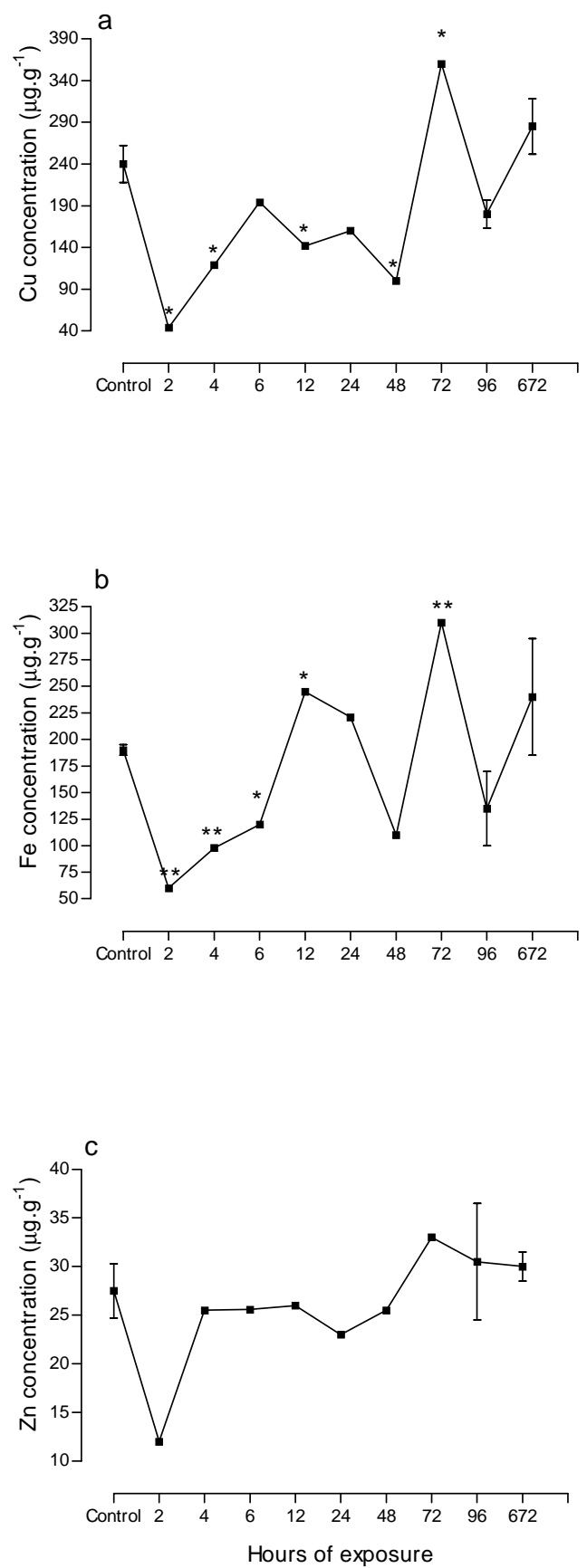

Figure 4

Time dependent bioconcentration of copper, iron and zinc in liver tissue of T. sparrmanii. Liver samples were pooled to obtain $1 \mathrm{~g}$ dry mass of tissue for each exposure group hence the lack of replicates for some exposure groups. Concentrations are presented as mean \pm standard error. Asterisks represent significant differences ${ }^{*}-P<0.05$ and ${ }^{* *}$ - $\left.P<0.005\right)$ from the control values ( $n=5$ for all exposures except $0 h, 96 h$ and $672 h$ where $n=10)$. Note the $x$-axis is not according to scale.

significantly $(\mathrm{P}<0.05)$ following $2 \mathrm{~h}$ of exposure to the $\mathrm{Cu}-\mathrm{Fe}-\mathrm{Zn}$ mixture. Although there was a subsequent increase in $\mathrm{Cu}$ and $\mathrm{Zn}$, the concentrations still remained significantly lower than the control concentrations (Figs. $4 \mathrm{a}$ and $4 \mathrm{c}$ ). It was only after the $48 \mathrm{~h}$ exposure that concentrations increased above control values. Copper concentrations decreased slightly below control values after $96 \mathrm{~h}$ 
exposure, whereas the slight decrease in $\mathrm{Zn}$ did not go below control concentrations. Iron concentrations in liver tissue displayed a similar tendency with significant decreases $(\mathrm{P}<0.05)$ after $2 \mathrm{~h}$ of exposure (Fig. 4b). However, Fe concentrations in the liver increased significantly only after $12 \mathrm{~h}$ exposure. As with $\mathrm{Cu}$ and $\mathrm{Zn}$, the Fe concentrations decreased after the $96 \mathrm{~h}$ exposure period but increased above control values following long-term exposure.

\section{Discussion}

Metal uptake by aquatic organisms is a two-phased process, which involves initial rapid adsorption or binding to the surface, followed by a slower transport into the cell interior (Crist et al., 1988). In epithelial tissues the last step is the rate-limiting factor in transepithelial movement of metals (Foulkes, 1988). Transport of metals into the intracellular compartment may be facilitated by either diffusion of the metal ion across the cell membrane or by active transport by a carrier protein (Brezonik et al., 1991). A third process involved in determining metal uptake, i.e. speciation of the metals in the medium before contact with the gill epithelia was not investigated in this study.

\section{Metal uptake by gills}

Gill surfaces are the first target of water-borne metals (Spicer and Weber, 1991). The micro-environment of the gill surface consists of an epithelial membrane which primarily contains phospholipids covered by a mucous layer (Bolis et al., 1984; Van de Winkel et al., 1986). The constituents of the external gill surface have a $\mathrm{pK}$ value of 3.6 (Reid, 1990) and at environmentally relevant $\mathrm{pH}$ values $(\mathrm{pH}>5)$, these constituents of the gill epithelia will be fully ionised, resulting in negatively charged gill surfaces and potential gillmetal interaction sites (Reid and MacDonald, 1991). The $\mathrm{pK}$ value refers to the condition where the anion concentration (A') is equal to the concentration of the conjugate (HA).

The extent of metal interaction with biological complexes varies widely among metals and has resulted in the development of a number of approaches to provide a measure of predictive relationships for these complexation patterns. Two of the most widely used approaches are:

- Correlations based on the metal ion size (the ionic radius or a function of charge: radius ratio),

- Correlations based on metal ion electronegativity (Nieboer and Richardson, 1980; Brezonik et al., 1991).

According to Nieboer and Richardson (1980) the relative binding affinity of a metal for biological ligands is a function of the tendency of a metal to form ionic vs. covalent bonds (metal electronegativity), as well as the chemistry of the particular ligand. Therefore, metal binding to gill surfaces could primarily be determined by the ionic interactions with the epithelial tissue (Reid and MacDonald, 1991). Ionic interactions are characteristic of oxygen-rich ligands, suggesting that the oxygen-rich centres of the carboxylate, sulphate and phosphate groups act as metal receptors, whereas covalent interactions typically bind to nitrogen- or sulphurrich ligands, which are characteristic of sulphydryl, thioether, nitrogen and amino groups (Reid and MacDonald, 1991).

The bioconcentration kinetic patterns of the metals in the metal mixture under investigation can best be explained by the two mechanisms mentioned above (viz. ionic and covalent correlations). The ionic and covalent indices for $\mathrm{Cu}, \mathrm{Fe}$ and $\mathrm{Zn}$ which are calculated according to the formulae of Nieboer and Richardson

\begin{tabular}{|c|c|c|}
\hline \multicolumn{3}{|c|}{$\begin{array}{l}\text { TABLE } 2 \\
\text { lonic and covalent indexes calculated } \\
\text { for } \mathrm{Cu}, \mathrm{Fe} \text { and } \mathrm{Zn} \text { using the formulae of } \\
\text { Nieboer and Richardson (1980) where } \\
\mathrm{Z} \text { represents the formal charge of the } \\
\text { metal, } X_{m} \text { the metal-ion electro- } \\
\text { negativity and } \mathrm{r} \text { the ionic radius. }\end{array}$} \\
\hline & $\begin{array}{l}\text { Ionic index } \\
\left(Z^{2} \cdot r^{-1}\right)\end{array}$ & $\begin{array}{l}\text { Covalent index } \\
\left(X_{m} \cdot r\right)\end{array}$ \\
\hline Copper & 5.4 & 3.0 \\
\hline Iron & 5.1 & 2.5 \\
\hline Zinc & 5.4 & 2.0 \\
\hline
\end{tabular}

(1980) are presented in Table 2.

Based on these index values, it is possible to predict that $\mathrm{Cu}$ (and possibly Fe) will have a tendency to bind to a more diverse selection of ligands and it could, therefore, be expected that the gill binding capacity would be greater for these metals than for $\mathrm{Zn}$. This prediction was substantiated by significant increases of $\mathrm{Cu}$ and $\mathrm{Fe}$ observed in the gill tissue (Fig. 2). The significant decreases in $\mathrm{Zn}$ concentrations in gill tissue could, in turn, be attributed to its displacement from binding sites by the more competitive metals in the metal mixture and the subsequent uptake into the blood stream. Wepener (1997) demonstrated the displacement of the $\mathrm{Ca}^{2+}$, following exposure to the same metal mixture. These findings support the gill surface interaction model proposed by Pagenkopf (1983) which states that the rate of metal-gill interactions is rapid and that competition occurs between metals, water hardness ions, and $\mathrm{H}^{+}$. Dethloff et al. (1999) found that gill $\mathrm{Cu}$ concentrations of rainbow trout increased following exposure to a metal mixture containing $\mathrm{Cu}$ and $\mathrm{Zn}$. The $\mathrm{Zn}$ concentrations were, however, highly variable but did not result in any significant alterations when compared to the control. Other studies found that adsorption of $\mathrm{Cu}$ to the gills of freshwater fish was extremely rapid, occurring within the first hour of exposure (Playle et al., 1992; Grosell et al., 1997).

Bioconcentration kinetic studies showed that external interaction sites have a finite capacity and $\mathrm{Cu}$ concentrations as low as $\left.13 \mu \mathrm{g} \cdot\right|^{-1}$ resulted in saturation of gill ligands (Laurén and MacDonald, 1987). A low affinity of the gill surface for a metal allows the metal to pass through the plasma membrane into the intercellular compartment (Reid and MacDonald, 1991). Since no distinction was made in this study between metals adsorbed to surface ligands or bioconcentration in the gill tissue, it could be assumed that $\mathrm{Cu}$ bioconcentration would only occur within the gill tissue once the affinity of $\mathrm{Cu}$ binding sites on the external surface has decreased due to saturation. Once inside the intracellular compartments of the gill there is a greater variety of binding sites e.g. gluthatione, metallothioneins and ATPases. As $\mathrm{Cu}$ has the highest covalent index value it could also be expected that it would be more competitive than $\mathrm{Zn}$ for the available intracellular nitrogen and sulphur-rich ligands. This is shown by the continued increase in $\mathrm{Cu}$ concentrations in gill tissue following a $12 \mathrm{~h}$ exposure to the metal mixture.

Displacement of $\mathrm{Zn}$ by more competitive $\mathrm{Cu}$ (and possibly Fe) ions, and the subsequent binding of the latter to oxygen-rich ligands on the external gill surface and the intercellular nitrogen, sulphurrich ligands and metallothioneins (MT), resulted in Zn traversing the gill tissue and entering the bloodstream. Given that MT has a high affinity for $\mathrm{Cu}$ (higher than for $\mathrm{Zn}$ ) (Hamer, 1986) it is highly 
likely that this was indeed the case. As a result there is a differential uptake of $\mathrm{Zn}$ and this is evident from the increased plasma $\mathrm{Zn}$ concentrations (Fig. 3). Spry et al. (1988) and Zia and McDonald (1994) also observed this phenomenon where $\mathrm{Zn}$ concentrations increased in the plasma but not in the gill tissue, suggesting that $\mathrm{Zn}$ may enter the gill tissue and pass through it. Significant accumulation of $\mathrm{Zn}$ in gill tissue was only seen when fish were exposed to high $\mathrm{Zn}$ concentrations. This mechanism is most probably the reason why $\mathrm{Zn}$ in gill tissue of rainbow trout did not reflect the intensity of the external metal concentrations during studies conducted by Hughes and Flos (1978). Villegas-Navarro and Villarreal-Treviño (1989) reported that Zn uptake by the Texas cichlid (Cichlasoma cyanoguttatum) was greater than the uptake of $\mathrm{Pb}$ and $\mathrm{Cu}$. These results are confirmed by the low retention of $\mathrm{Zn}$ in gill tissue of minnows (Phoxinus phoxinus) following exposure to water-borne Cd and Zn (Wicklund-Glynn, 1991). The results of Spry and Wood (1988) preclude passive movement of $\mathrm{Zn}$ thorough gill tissue into the bloodstream due to differences in electrochemical and concentration gradients. They attributed Zn uptake to morphological changes in the gill tissue, i.e. proliferation of chloride cells, which resulted in active $\mathrm{Zn}$ uptake via carrier molecules or selective pores.

\section{Metal uptake into the plasma}

Once in the bloodstream, metals are transported by binding to specific plasma proteins. Bentley (1991) isolated a serum albumin in channel catfish (Ictalurus puntatus), which appeared to be specific for $\mathrm{Zn}$ binding. These findings suggested that a single protein with steric factors, which influence access to binding sites, or the involvement of non-sulphydryl, non-electrostatic sites such as imidazole groups, was responsible for specificity towards $\mathrm{Zn}$ binding. The presence of such a protein would, therefore, prevent more competitive metals from competing for binding sites in the plasma. Furthermore, this protein maintained physiologically active "free" $\mathrm{Zn}$ at low concentrations despite the high total $\mathrm{Zn}$ concentration in the plasma. Fletcher and Fletcher (1978) and Bentley (1991) found that nearly all the $\mathrm{Zn}$ bound to plasma proteins was freely exchangeable. The presence of such a $\mathrm{Zn}$ specific protein in the plasma of $T$. sparrmanii would account for the drastic $\mathrm{Zn}$ increases measured following the first $4 \mathrm{~h}$ of exposure. The pulsed decreases and increases in $\mathrm{Zn}$ concentrations recorded for the remainder of the exposure period can be attributed to the freely bound $\mathrm{Zn}$ being eliminated or sequestered by different tissues, i.e. liver. This depuration mechanism was proposed by Grobler-Van Heerden et al. (1991) following exposure of $T$. sparrmanii to different concentrations of $\mathrm{Zn}$. These authors speculated that there was a finite bioconcentration level for $\mathrm{Zn}$ and once this level was reached, elimination of the metal took place.

Iron is bound to the protein transferrin in the plasma (Guyton, 1982), which has a low binding affinity for $\mathrm{Cu}$ and $\mathrm{Zn}$ (Bentley, 1991). Studies by Grobler-van Heerden et al. (1991) showed that T. sparrmanii also concentrated Fe to finite levels before elimination of the excess metals took place. Results from this study support the latter findings and it was particularly interesting to note that the metal concentration elimination threshold for $\mathrm{Fe}$ was much higher than for $\mathrm{Zn}$. Increases in Fe during the initial $24 \mathrm{~h}$ exposure period corresponded with increases in red blood cell formation during the same period (Wepener, 1997). However, it is unlikely that increased plasma $\mathrm{Fe}$ was related to increased haemoglobin, since all $\mathrm{Fe}$ concentrations were measured in haemolysis-free plasma samples. It could, therefore, be assumed that increases in plasma $\mathrm{Fe}$ concentrations were due to the uptake of the metal as a result of increased external concentrations.

The results obtained for $\mathrm{Cu}$ concentrations showed marked decreases in plasma samples during the first $48 \mathrm{~h}$ of exposure with concentrations only increasing above control values following four weeks of exposure. Most other studies showed that plasma $\mathrm{Cu}$ concentrations only increased following long-term exposure (Yamamoto et al., 1977; Stagg and Shuttleworth, 1982). The rapid clearance of $\mathrm{Cu}$ from plasma during the initial exposure to exogenous $\mathrm{Cu}$ has been reported by Grosell et al. (1997) and Campbell et al. (1999). There are two possible explanations for the observed decreases. Firstly, $\mathrm{Cu}$ is loosely bound to the protein ceruloplasmin in the plasma of fish (Yamamoto et al., 1977). Due to the complicated and extensive vascular network in the gill, any bloodborne metal will be in intimate contact with the gill tissue and increased $\mathrm{Cu}$ concentrations in the gill can, therefore, be attributed to both exogenous exposures from the environment and endogenous exposure from the blood. Noël-Lambot et al. (1978) showed that exposure of Anguilla anguilla to elevated ambient $\mathrm{Cu}$ induced the production of MT, which is responsible for binding $\mathrm{Cu}$, in gill tissue. During the present study the de novo production of MT, or other metal-binding proteins in gill tissue could have been responsible for the depuration of loosely bound $\mathrm{Cu}$ from cerloplasmin, thereby reducing the $\mathrm{Cu}$ concentrations in the plasma. Secondly, the highly competitive nature of $\mathrm{Cu}$ for binding sites on the external surface and MT in the gill tissue most probably resulted in most of the $\mathrm{Cu}$ binding to these sites, thereby slowing down $\mathrm{Cu}$ turnover into the bloodstream. Dethloff et al. (1999) described the same mechanisms for reduced $\mathrm{Cu}$ turnover in rainbow trout following exposure to a $\mathrm{Cu}$ and $\mathrm{Zn}$ mixture. Therefore, $\mathrm{Cu}$ concentrations did not increase in the plasma during the first $48 \mathrm{~h}$ of exposure. This is supported by the results obtained for $\mathrm{Cu}$ concentrations in the liver tissue (Fig. 4), where $\mathrm{Cu}$ concentrations only increased above normal following $72 \mathrm{~h}$ of exposure. It is also possible that the rapid changes in $\mathrm{Cu}$ stores in the plasma resulted in a depletion of liver-bound $\mathrm{Cu}$ through renal excretion as found by Grosell et al. (1997) in rainbow trout which were exposed to $\mathrm{Cu}$.

\section{Metal uptake by the liver}

The liver is the main organ for metal regulation in mammals and it appears to have a similar function in fish (Heath, 1987). Exposure to metals results in induction of MT production and subsequent binding of metals to the protein (Hogstrand and Haux, 1991). According to Brown and Parsons (1978) MT always exists in a metal-saturated form and, therefore, the formation of MT is a de novo process. Since the control group of fish has never been exposed to metals, the concentrations of $\mathrm{Cu}, \mathrm{Fe}$ and $\mathrm{Zn}$ measured at time zero are attributed to normal background levels. These relatively high metal concentrations, in the absence of metal stress, can be attributed to the binding of notably $\mathrm{Cu}$ and $\mathrm{Zn}$ to metalbinding proteins (MT and other proteins involved in metal metabolism) in the liver (Krezoski et al., 1988).

The immediate significant decreases of all three metals in the liver tissue were unexpected since most research showed that metal exposure leads to increased metal uptake by the liver due to the formation of MT. See Hodson (1988) and Roesijadi (2000) for extensive reviews on MT induction by metals. Most studies deal with metal concentrations in the liver in conjunction with increased MT levels and scant attention was paid to liver-metal concentrations during the initial stages (i.e. pre-MT formation) of exogenous metal exposure. Although Olafson (1981) showed that MT levels reached a plateau within $20 \mathrm{~h}$ of exposure to $\mathrm{Cd}$, this reaction to metal exposure cannot be regarded as a rapidly-acting stress 
response to promote the survival of fish under initial stressful conditions.

According to Pickering (1993) the stress response can be regarded as a mechanism that enables fish to avoid or overcome potentially threatening or harmful situations. Even though the response may vary according to different circumstances, there appears to be a common element in response to all forms of environmental stress. This involves the activation of the sympathetico-chromaffin system to release catecholamines and the hypothalamic-pituitary-interrenal axis for secretion of corticosteroid hormones into the circulatory system. Secretion of catecholamines is particularly rapid in response to respiratory stress and promotes the survival of fish by increasing the blood supply to the gills, increasing the blood-oxygen carrying capacity and increasing intermediate metabolism to provide a readily accessible energy supply (Pickering, 1993). Catecholamines induce glycogenolysis (Klee et al., 1990), gluconeogenesis (Morata et al., 1982) and lipid mobilisation (Sheridan, 1987) in the liver of fish. It is, therefore, highly probable that catecholamines (or other hormones) are responsible for inducing other adaptive changes in liver tissue. Based on this assumption, as well as the observed significant decreases in liver metal concentrations, it is intriguing to speculate that internal metal fluxes may have taken place in reaction to stress-induced secretion of hormones, thereby resulting in the release of the naturally bound metals in the liver. These metals were most probably depurated through bilary excretion into the intestine and/or renal excretion. Hence, no increases were observed in the arterial blood. Grosell et al. (1997) illustrated rapid changes in $\mathrm{Cu}$ stores of the body compartments other than gill tissue and it is, therefore, possible that similar mechanisms may be involved in the compartmental distribution of $\mathrm{Zn}$.

This proposed mechanism resulted in significant decreases of $\mathrm{Cu}$ and $\mathrm{Zn}$ in the liver of $T$. sparrmanii after $2 \mathrm{~h}$ of exposure to the metal mixture. The subsequent increased $\mathrm{Zn}$ uptake in the bloodstream is reflected by increased $\mathrm{Zn}$ liver concentrations, whereas the $\mathrm{Cu}$ concentrations remained significantly lower than those of the control levels. This is an indication that the ensuing increased availability of non-MT metal-binding proteins in the liver resulted in uptake of excess $\mathrm{Zn}$, which entered the bloodstream through the gill tissue. Stimulation of $\mathrm{Zn}$ uptake by liver tissue following $\mathrm{Cd}$ and $\mathrm{Cu}$ exposure was also recorded by Noël-Lambot et al. (1978) and Buckley et al. (1982). The increased uptake of $\mathrm{Zn}$ in the presence of other metals can most likely also be attributed to the proposed stress-response mechanism, which liberates and depurates metals from metal-binding proteins in the liver, thus providing available proteins for the binding of excess metals. This is most probably an intermediary response mechanism, which functions until sufficient MT has been produced to bind to the excess accumulated metals. However, $\mathrm{Zn}$ concentrations did not increase significantly above the control levels. This is probably related to the fact that $\mathrm{Zn}$ does not sequester preferentially in the liver (Sorensen, 1991). This is supported by studies conducted by Bradley et al. (1985) who found that hepatic $\mathrm{Zn}$ concentrations do not respond to increased dissolved $\mathrm{Zn}$, even in the presence of $\mathrm{Cu}$.

The fact that $\mathrm{Cu}$ concentrations remained lower than control concentrations for the first $72 \mathrm{~h}$ of exposure was probably related to the disturbance of $\mathrm{Cu}$ turnover recorded in the gills and bloodstream. Increased $\mathrm{Cu}$ concentrations were only recorded after 72 $\mathrm{h}$ of exposure, indicating the saturation of gill metal binding sites in the gill tissue and subsequent $\mathrm{Cu}$ uptake into the bloodstream. The significant decreases in $\mathrm{Fe}$ concentrations during the first $6 \mathrm{~h}$ of exposure are attributed to $\mathrm{Fe}$ mobilisation for haemoglobin synthesis. This was demonstrated by Wepener (1997) where increased red blood cell counts, haematocrit and haemoglobin concentrations were recorded following exposure of $T$. sparrmanii to the same metal mixture. Iron concentrations in the liver only increased significantly after $12 \mathrm{~h}$ exposure and this is attributed to excess accumulated iron being stored in the form of ferritin (Guyton, 1982). Based on the uptake of $\mathrm{Cu}$ and $\mathrm{Fe}$ by the liver, it was clear that the $\mathrm{Fe}$ uptake into the bloodstream from the gill surface was more rapid than the $\mathrm{Cu}$ uptake. Thus, the lower the affinity of the gill surfaces for a particular metal, the greater the uptake into the internal environment.

\section{Interaction of individual metals in mixture with tissues}

The metals investigated in this study are all essential metals and therefore they would occur naturally in all the tissues. The metals would be subjected to different mechanisms which would ensure metal homeostasis in the tissues. The interaction of the individual metals within the mixture appeared to be antagonistic towards competition among the elements for transport systems and storage proteins. Based on the results of mammalian toxicity studies, Gawthorne (1987) noted that "the bioavailable fraction of each element can be regarded as being in balance with that of the other two, and, therefore, changes in the concentration of one would distort the metabolism of the others". The antagonistic action of the metals in the mixture on uptake and tissue distribution of the individual metals was further supported by the results from the physiological endpoints that were recorded in conjunction with the metal analysis in tissues reported in this paper. Wepener (1997) demonstrated that physiological disturbances (viz. osmoregulation and acid-base balance) were more pronounced following exposure to single metals than exposure to mixtures of the individual metals.

\section{Ecological relevance of uptake bioassay}

The exposure concentrations used in the bioassays were based on actual measured concentrations in water samples from the Olifants River (Kruger National Park). The concentrations were expressed as total metal concentrations and, as such, cannot be compared to the existing South African Water Quality Guidelines (DWAF 1996). However, Wepener et al. (2000) reported that dissolved $\mathrm{Cu}$ and $\mathrm{Zn}$ concentrations in the Olifants River were comparable to concentrations reported for large metal contaminated rivers. The reported dissolved concentrations in the Olifants River exceeded the safety levels prescribed by the Water Quality Guidelines.

This study showed that the relatively short-term exposure (maximum up to $28 \mathrm{~d}$ ) of fish to the metal mixture did not result in significant bioaccumulation, with only significantly higher $\mathrm{Cu}$ concentrations in gill tissue and $\mathrm{Zn}$ in plasma when compared to the control levels. When comparing the bioassay bioaccumulation results to actual metal bioaccumulation in tilapia (Oreochromis mossambicus) from the Olifants River (Table 3) it was evident that metal concentrations were all within the same range. When comparing the $\mathrm{Cu}$ concentrations in the livers of $O$. mossambicus from the metal-contaminated Olifants River to the higher $\mathrm{Cu}$ concentrations in the uncontaminated control livers of $T$. sparrmanii it clearly demonstrates metal level differences between species. The higher Fe concentrations in the field samples were due to the metals being measured in whole blood as opposed to plasma in the bioassays. The bioaccumulation of $\mathrm{Zn}$ was greater in the field samples from the Olifants River than in the bioassay tissues. This cautions against the use of bioassays to predict environmental tissue concentrations. This is due to the fact that it is not possible to experimentally simulate the complex physical and chemical 
TABLE 3

Range of copper, iron and zinc concentrations measured in gill, liver and blood samples of Oreochromis mossambicus from the Olifants River (Kruger National Park) and Tilapia sparrmanii during the current study. All concentrations are expressed in $\mu \mathrm{g} \cdot \mathrm{g}^{-1}$ based on dry mass of the tissue or $\mathrm{mg} \cdot \mathrm{l}^{-1}$ in the case blood or plasma.

\begin{tabular}{|c|c|c|c|c|}
\hline Metal & Gill & $\begin{array}{c}\text { Blood/ } \\
\text { Plasma }\end{array}$ & Liver & Reference \\
\hline $\mathrm{Cu}$ & $1.5-6$ & $1.1-7.2$ & $44-360$ & This study \\
$\mathrm{Fe}$ & $30-102$ & $22-97$ & $60-290$ & This study \\
$\mathrm{Zn}$ & $14-40$ & $20-64$ & $12-37$ & This study \\
$\mathrm{Cu}$ & $15-31$ & $1.6-4.8$ & $93-146$ & Wepener, 1997 \\
$\mathrm{Fe}$ & $690-800$ & $123-320$ & $320-641$ & Wepener, 1997 \\
$\mathrm{Zn}$ & $108-158$ & $5-34$ & $73-87$ & Wepener, 1997 \\
$\mathrm{Cu}$ & $1-160$ & - & $2-843$ & Kotze et al., 1999 \\
$\mathrm{Fe}$ & $190-1673$ & - & $319-6908$ & $\begin{array}{c}\text { Robinson and Avenant- } \\
\text { Oldewage, 1997 }\end{array}$ \\
$\mathrm{Zn}$ & $13-625$ & - & $4-781$ & Kotze et al., 1999 \\
\hline
\end{tabular}

conditions that affect bioaccumulation in the natural environment. The value of bioassay-based bioaccumulation experiments lies in the information that it provides to understand mechanisms of metal uptake and distribution.

\section{Conclusions}

Gill tissue in banded tilapia is the initial site of accumulation of water-borne metals. Although the fish were exposed to a metal mixture, the interactions between metals and the external gill surface, as well as the subsequent uptake rate, were associated with the particular chemical properties of individual metals. The tendency of the individual metals in the metal mixture to bind to the external gill surface via ionic bonds, and to gill cytosolic compounds via covalent bonds, was $\mathrm{Cu}>\mathrm{Fe}>\mathrm{Zn}$. The ensuing uptake rates into the extracellular compartment (blood) and intracellular compartment (liver tissue) were $\mathrm{Zn}>\mathrm{Fe}>\mathrm{Cu}$. The toxic effects of $\mathrm{Cu}$ and $\mathrm{Fe}$ were, therefore, primarily exerted on the gill surface and in the gill cytosol, whereas the toxic action of $\mathrm{Zn}$ was limited primarily to the internal organs.

It is acknowledged that much of the mechanistic interpretation is speculative and is based on published information available on the actions of individual metals. This study has highlighted the importance of distinguishing between the accumulation of exogenous metal sources and the changes in tissue concentrations due to endogenous metal shifts. Understanding and clarifying the mechanisms involved in uptake and interactions among the different metals in a mixture could be accomplished by using radioactive metals for exposure experiments.

\section{Acknowledgements}

The authors wish to thank the Department of Zoology, Rand Afrikaans University for the use of facilities and equipment and the Water Research Commission for the financial support, which made the study possible.

\section{References}

BENTLEY PJ (1991) A high-affinity zinc-binding plasma protein in channel catfish (Ictalurus punctatus). Comp. Biochem. Physiol. 100C (3) 491-494.

BOLIS CLCAMBRIA A and FAMA M(1984) Effects of acid stress on fish gills. In: L Bolis, J Zadunaisky and R Gilles (eds.) Toxins, Drugs And Pollutants in Marine Mammals, Springer Verlag, Berlin. 122-129.

BRADLEY RW, DUQUESNAY C and SPARGUE JB (1985) Acclimation of rainbow trout, Salmo gairdneri Richardson to zinc: Kinetics and mechanism of enhanced tolerance induction. J. Fish Biol. 27 367-379.

BREZONIK PL, KING SO and MACH CE (1991) The influence of water chemistry on trace metal bioavailability and toxicity to aquatic organisms. In: MC Newman and AW McIntosh (eds.) Metal Ecotoxicology: Concepts and Applications, Lewis Publishers Inc., Michigan. 1-26.

BROWNDA and PARSONS TR (1978) Relationship between cytoplasmic distribution of mercury and toxic effects to zooplankton and chum salmon, Onchorhynchus keta, exposed to mercury in a controlled ecosystem. J. Fish. Res. Board of Canada. 35 880-884.

BUCKLEY JT, ROCH M, MCCARTER, JA, RENDELL CA and MATHESONAT (1982) Chronic exposure of Coho salmon to sublethal concentrations of copper-I. Effect on growth, on accumulation and distribution of copper, and on copper tolerance. Comp. Biochem. Physiol. 72C (1) 15-19.

CAMPBELL HA, HANDY RD and NIMMO M (1999) Copper uptake kinetics across the gills of rainbow trout (Oncorhynchus mykiss) measured using an improved isolated perfused head technique. Aquat. Toxicol. 46 177-190.

CARPENÉ E, CATTANI O, SERRAZANETTI GP, FEDRIZZI G and CORTESI P (1990) Zinc and copper in fish from natural waters and rearing ponds in Northern Italy. J. Fish Biol. 37 293-299.

CRIST RH, OBERHOLSER K, SCHWARTZ D, MARZOFF J, RYDER $\mathrm{D}$ and CRIST DR (1988) Interactions of metals and protons with algae. Environ. Sci. Technol. 22 755-760.

DETHLOFF GM, SCHLECK D, HAMM JT and BAILEY HC (1999) Alterations in the physiological parameters of rainbow trout (Oncorhynchus mykiss) with exposure to copper and copper/zinc mixtures. Ecotoxicol. Environ. Safety 42 (3) 253-254.

DU PREEZ HH and STEYN GJ (1992) A preliminary investigation of the concentration of selected metals in the tissues and organs of the tigerfish (Hydrocynus vittatus) from the Olifants River, Kruger National Park, South Africa. Water SA 18 (2) 131-136. 
DWAF (DEPARTMENT OF WATER AFFAIRS AND FORESTRY) (1996) South African Water Quality Guidelines. Volume 7: Aquatic Ecosystems. Department of Water Affairs and Forestry, Pretoria.

FLETCHER PE and FLETCHER GL (1978) The binding of zinc to the plasma of winter flounder (Pseudopleuronectus americanus): Affinity and specicivity. Canadian J. Zool. 56 114-120.

FOULKES EC (1988) On the mechanism of transfer of heavy metals across cell membranes. Toxicol. 52 263-272.

GAWTHORNE JM (1987) Copper interactions. In: J McC Howell and JM Hawthorne (eds.) Copper in Animals and Man Vol. I. CRC Press, Boca Raton. 87-90.

GOSS GG and WOOD CM (1988) The effects of acid and acid/aluminum exposure in circulating plasma cortisol levels and other blood parameters in the rainbow trout, Salmo gairdneri. J. Fish Biol. 32 (1) 63-76.

GROBLER E, DU PREEZ HH and VAN VUREN JHJ (1989) Toxic effects of zinc and iron on the routine oxygen consumption of Tilapia sparrmanii (Cichlidae). Comp. Biochem. Physiol. 94C (1) 207-214.

GROBLER-VAN HEERDEN E, VAN VUREN JHJ and DU PREEZ HH (1991) Bioconcentration of atrazine, zinc and iron in the blood of Tilapia sparrmanii (Cichlidae). Comp. Biochem. Physiol. 100C (3) 629-633.

GROSELL MH, HOGSTRAND C and WOOD CM (1997) Cu uptake and turnover in both $\mathrm{Cu}$-acclimated and non-acclimated rainbow trout (Oncorhychus mykiss). Aquat. Toxicol. 38 (4) 257-276.

GUYTON AC (1982) Human Physiology and Mechanisms of Disease. WB Saunders Company, Philadelphia. 279-283.

HAMER DH (1986) Metallothionein. Annu. Rev. Biochem. 55 913-951.

HEATH AG (1987) Water Pollution and Fish Physiology. CRC Press Inc., Boca Raton. 145 pp.

HODSON PV (1988) The effect of metal metabolism on uptake, disposition and toxicity in fish. Aquat. Toxicol. 11 3-18.

HOGSTRANDC and HAUX C (1991) Binding and detoxification of heavy metals in lower vertebrates with reference to metallothionein. Comp. Biochem. Physiol. 100C (1/2) 137-141.

HUGHES GM and FLOS R (1978) Zinc content of the gills of rainbow trout (S. gairdneri) after treatment with zinc solutions under normoxic and hypoxic conditions. J. Fish Biol. 13 717-728.

KLEE M, EILERSON C and SHERIDAN MA (1990) Nutritional state modulates hormone-mediated hepatic glycogenolysis in chinook salmon (Oncorhynchus tshawytscha). J. Exp. Zool. 254 202-207.

KOTZEP, DU PREEZHH and VAN VUREN JHJ (1999) Bioaccumulation of copper and zinc in Oreochromis mossambicus and Clarias gariepinus from the Olifants River, Mpumalanga, South Africa. Water SA 25 (1) 99-110.

KREZOSKI S, LAIB J, ONANA P, HARTMANN T, CHEN P, SHAW CF and PETERING DH (1988) Presence of $\mathrm{Zn}, \mathrm{Cu}$-binding protein in liver of freshwater fishes in the absence of elevated exogenous metal: Relevance to toxic metal exposure. Mar. Environ. Res. 24 (1-4) 147 150.

KUMAR A and MATHUR RP (1991) Bioaccumulation kinetics and organ distribution of lead in a fresh water teleost, Colisa fasciatus. Environ. Technol. 12 731-735.

LAURÉN DJ and MACDONALD DG (1987) Acclimation to zinc by rainbow trout, Salmo gairdneri: Biochemistry. Can.J. Fish.Aquat. Sci. 44 105-111.

LEWIS M (1978) Acute toxicity of copper, zinc and manganese in single and mixed salt solutions to juvenile longfin dace, Angosia chyrogaster. J. Fish Biol. 13 695-700.

MALLATT J (1985) Fish gill structural changes induced by toxicants and other irritants: A statistical review. Can. J. Fish. Aquat. Sci. 42 630-648.

MOHAN D and CHOUDHARY A (1991) Zinc accumulation in a few tissues of fish, Puntius sophore (Ham.) after sublethal exposure. J. Nature Cons. 3 (2) 205-208.

MORATA P, VARGAS AM, PITA ML and SANCHEZ-MEDINA F (1982) Involvement of gluconeogenesis in hyperglycaemia induced by glucagon, adrenaline and cyclic AMP in rainbow trout. Comp. Biochem. Physiol. 73A 379-381.

MUKHOPADHYAY MK and KONAR SK (1985) Effects of copper, zinc and iron mixture on fish and aquatic ecosystem. Environ. Ecol. 3 (1) 58-64.
NIEBOER E and RICHARDSON DHS (1980) The replacement of the nondescript term "heavy metals" by a biologically and chemically significant classification of metal ions. Environ. Pollut. (Series B) 1 3-26.

NOËL-LAMBOT F, GIERDAY C and DISTECHE A (1978) Distribution of $\mathrm{Cd}, \mathrm{Zn}$ and $\mathrm{Cu}$ in liver and gills of the eel Anguilla anguilla with special reference to metallothioneins. Comp. Biochem. Physiol. 61C 171-187.

OLAFSON RW (1981) Differential pulse polarographhic determination of marine metallothionein induction kinetics. J. Biol. Chem. 256 1263-1268.

PAGENKOPF GK (1983) Gill surface interaction model for trace metal toxicity to fish: Role of complexation, $\mathrm{pH}$ and water hardness. Environ. Sci. Technol. 17 342-347.

PELGROM SMGJ, LOCK RAC, BALM PHM and WENDELAAR BONGA SE (1995) Integrated physiological response of tilapia, Oreochromis mossambicus, to sublethal copper exposure. Aquat. Toxicol. 32 303-320.

PERES I and PIHAN JC (1991) Study of the accumulation of copper by carp (Cyprinus carpio L.). Adaptation analyses of bioconcentration by the gills. Environ. Technol. 12 169-177.

PICKERING AD (1993) Endocrine-induced pathology in stressed salmonid fish. Fish. Res. 17 35-50.

PLAYLE RC, GENSEMER RW and DIXON DG (1992) Copper accumulation on gills of fathead minnows: influence of water hardness, complexation and $\mathrm{pH}$ of the gill micro-environment. Environ. Toxicol.Chem. 11 381-391.

REID SD (1990) Metal-gill Surface Interactions in Rainbow Trout (Onchorhynchus mykiss). Ph.D.Thesis, McMaster Univ., Hamilton. Canada.

REID SD and MCDONALD DG (1991) Metal binding activity of the gills of the rainbow trout (Onchorhynchus mykiss). Can. J. Fish. Aquat. Sci. 48 1061-1068.

ROBINSON J and AVENANT-OLDEWAGEA (1997) Chromium, copper, iron and manganese bioaccumulation in some organs and tissues of Oreochromis mossambicus from the lower Olifants River, inside the Kruger National Park. Water SA 23 (4) 387-403.

ROESIJADI G (2000) Metal transfer as a mechanism for metallothioneinmediated metal detoxification. Cell. Mol. Biol. 46 (2) 293-405.

SEYMORE T, DU PREEZ HH, VAN VUREN JHJ and DEACON AR (1994) Variation in selected water quality variables and the metal concentrations in the sediment of the lower Olifants and Selati Rivers, South Africa. Koedoe 37(2) 1-18.

SHERIDAN MA (1987) Effects of epinephrine and norepinephrine on lipid mobilization from coho salmon liver incubated in vitro. Endocrinol. 126 2234-2239.

SORENSON EM (1991) Metal Poisoning in Fish. CRC Press, Boca Raton. $251 \mathrm{pp}$.

SPICER JI and WEBER RE (1991) Respiratory impairment in crustaceans and molluscs due to exposure to heavy metals. Comp. Biochem. Physiol. 100C (3) 339-342.

SPRY DJ and WOOD CM (1985) Zinc influx across the isolated, perfused head preparation of the rainbow trout (Salmo gairdneri) in hard and soft water. Can. J. Fish. Aquat. Sci. 45 2206-2215.

SPRY DJ, HODSON PV and WOOD CM (1988) Relative contributions of dietary and waterborne zinc in the rainbow trout, Salmo gairdneri. Can. J. Fish. Aquat. Sci. 45 32-41.

STAGG RM and SHUTTLEWORTH TJ (1982) The accumulation of copper in Platichthys flesus L. and its effects on plasma electrolyte concentrations. J. Fish Biol. 20 491-500.

TSAI C and MCKEE JA (1980) Acute toxicity to goldfish of mixtures of chloramines, copper and linear alkylate sulfonate. Trans. Am. Fish. Soc. 109 132-141.

VAN DE WINKEL JG, VAN KUPPEVELT THMSM, JANSEN HMJ and LOCK RAC (1986) Glycosaminoglycans in the skin mucus of rainbow trout (Salmo gairdneri). Comp. Biochem. Physiol. 85B 473-475.

VILLEGAS-NAVARRO A and VILLARREAL-TREVIÑO CM (1989) Differential uptake of zinc, copper, and lead in Texas cichlid (Cichlasoma cyanoguttatum). Bull. Environ. Contam. Toxicol. 42 761-768. 
WEPENER V (1997) Metal Ecotoxicology of the Olifants River in the Kruger National Park and the Effect Thereof on Fish Haematology. Ph.D. Thesis, Rand Afr. Univ., Johannesburg, South Africa.

WEPENER V, VAN VUREN JHJ and DU PREEZ HH (1992) The effect of iron and manganese at an acidic $\mathrm{pH}$ on the hematology of the banded tilapia (Tilapia sparrmanii, Smith). Bull. Environ. Contam. Toxicol. 49 (4) 613-619.

WEPENER V, VAN VUREN JHJ and DU PREEZ HH (2000) Application of the equilibrium partitioning method to derive copper and zinc quality criteria for water and sediment: A South African perspective. Water SA 26 (1) 97-104.
WICKLUND-GLYNN A (1991) Cadmium and zinc kinetics in fish: Studies on water-borne ${ }^{109} \mathrm{Cd}$ and ${ }^{65} \mathrm{Zn}$ turnover and intracellular distribution in Minnows, Phoxinus phoxinus. Pharmacol. Toxicol. 69 485-491.

YAMAMOTO Y, ISHII T and IKEDA S (1977) Studies on copper metabolism in fishes. II. The site of copper accumulation in tissues of carp. Bull. Jap. Soc. Sci. Fish. 43 1327-1332.

ZAR RH (1996) Biostatistical Analysis. Prentice Hall, Englewood Cliffs, New York. 625 pp.

ZIA S and MCDONALD DG (1994) Role of the gills and gill chloride cells in metal uptake in the freshwater adapted rainbow trout, Oncorhynchus mykiss. Can. J. Fish. Aquat. Sci. 51 2482-2492. 